\title{
Mine water treatment with limestone for sulfate removal
}

\author{
Adarlêne M. Silva, Rosa M.F. Lima, Versiane A. Leão* \\ BioEHydrometallurgy Laboratory, Universidade Federal de Ouro Preto, Campus Morro do Cruzeiro, Ouro Preto, MG 35400-000, Brazil
}

\section{A R T I C L E I N F O}

\section{Article history:}

Received 2 November 2011

Received in revised form 4 March 2012

Accepted 25 March 2012

Available online 1 April 2012

\section{Keywords:}

Sulfate

Mine water

Limestone

Sorption

Fixed-bed models

Thomas model

\begin{abstract}
A B S T R A C T
Limestone can be an option for sulfate sorption, particularly from neutral mine drainages because calcium ions on the solid surface can bind sulfate ions. This work investigated sulfate removal from mine waters through sorption on limestone. Continuous stirred-tank experiments reduced the sulfate concentration from $588.0 \mathrm{mg} / \mathrm{L}$ to $87.0 \mathrm{mg} / \mathrm{L}$ at a 210 -min residence time. Batch equilibrium tests showed that sulfate loading on limestone can be described by the Langmuir isotherm, with a maximum loading of $23.7 \mathrm{mg} / \mathrm{g}$. Fixed-bed experiments were utilized to produce breakthrough curves at different bed depths. The Bed Depth Service Time (BDST) model was applied, and it indicated sulfate loadings of up to $20.0 \mathrm{~g} \mathrm{SO}_{4}{ }^{2-} / \mathrm{L}-$ bed as the flow rate increased from 1 to $10 \mathrm{~mL} / \mathrm{min}$. Thomas, Yoon-Nelson and dose-response models, predicted a maximum particle loading of $19 \mathrm{mg} / \mathrm{g}$. Infrared spectrometry indicated the presence of sulfate ions on the limestone surface. Sulfate sorption on limestone seems to be an alternative to treating mine waters with sulfate concentrations below the $1200-2000 \mathrm{mg} / \mathrm{L}$ range, where lime precipitation is not effective. In addition, this approach does not require alkaline $\mathrm{pH}$ values, as in the ettringite process.
\end{abstract}

(c) 2012 Elsevier B.V. All rights reserved.

\section{Introduction}

Sulfate is a major anion occurring in both natural waters and industrial effluents, such as those of the chemical and metallurgical industries [1,2], as well as in mine drainages either neutral or acid [3].

Compared with toxic metals, sulfate is only mildly hazardous. Therefore, many countries have no set guidelines for sulfate in drinking water. However, sulfate can affect the taste of water and can have laxative effects at concentrations above $600 \mathrm{mg} / \mathrm{L}$. Therefore, environmental agencies in many countries have set maximum values varying between 250 and $500 \mathrm{mg} / \mathrm{L}$ in both mine drainages and industrial effluents. When there is no limit for sulfate, it is common to define limits for total dissolved solids, implying that sulfate concentrations must comply with that value [4]. Considering the high concentrations typically found in some industrial effluents, treating sulfate is a considerable task.

Established methods for sulfate removal include the following: (i) biological treatment with sulfate-reducing bacteria; (ii) sorption technologies, including membrane and ion exchange and (iii) chemical precipitation as gypsum, barium sulfate or ettringite

\footnotetext{
* Corresponding author at: Bio\&Hydrometallurgy Laboratory, Department of Metallurgical and Materials Engineering, Campus Morro do Cruzeiro, s.n., Bauxita, Ouro Preto, MG 35400-000, Brazil. Tel.: +55 313559 1102; fax: +55 3135591561.

E-mail addresses: adarlenems@gmail.com (A.M. Silva), versiane@demet.em.ufop.br, versiane.ufop@gmail.com,va.leao@uol.com.br (V.A. Leão).
}

$\left(\mathrm{Ca}_{6} \mathrm{Al}_{2}\left(\mathrm{SO}_{4}\right)_{3}(\mathrm{OH})_{12} \cdot 26 \mathrm{H}_{2} \mathrm{O}\right)$ [3]. These treatments are well documented and a review on such technologies is available elsewhere [4]. Sulfate reduction relies on the use of sulfate as electron acceptor by sulfate reducing bacteria (SRB) during anaerobic digestion of organic matter. Most studies focusing on sulfate removal in bioreactors applied sulfate loadings around $2.0 \mathrm{~kg} \mathrm{SO}_{4}{ }^{2-} / \mathrm{m}^{3} \mathrm{~d}$ or lower values $[5,6]$, thereby the process is best suited to low or moderate sulfate loadings. The process usually produces residual sulfate concentrations below $500 \mathrm{mg} / \mathrm{L}$, but the residual chemical organic demand (COD) requires downstream treatment due to the presence of high acetate concentrations. The controlling step is sulfate reduction, which may require residence times as long as $24 \mathrm{~h}$ [7]. For the treatment of AMD, a preliminary step must be added whereby the drainage $\mathrm{pH}$ is increased (because SRB do not grow in acid conditions) as performed in the work of Maree et al. [8]. The $\mathrm{COD} / \mathrm{SO}_{4}{ }^{2-}$ ratio should be higher than 0.67 to ensure complete sulfate removal and thus the consumption of organic matter is large and usually constitutes the main cost of the process. The main advantages of biological sulfate reduction are the low volume of sludge produced and the recovery of base metals as sulfides. Despite such advantages, sulfate reduction is yet to be widely adopted by the mining industry as a strategy to remove sulfate to levels that comply with environmental regulations. It has been however successfully applied in the production of biogenic sulfide for base metal precipitation as demonstrated by the industrial operations commissioned worldwide by BIOTEQ and PAQUES.

Examples of membrane technologies applied to the treatment of mine waters comprise reverse osmosis and electrodialysis with the predominance of the former. Both processes also require AMD 


\begin{tabular}{|ll|}
\hline Nomenclature \\
BDST & Bed Depth Service Time \\
$C_{0}$ & initial solute concentration $(\mathrm{mg} / \mathrm{L})$ \\
$k$ & rate constant $(\mathrm{L} /(\mathrm{min} \mathrm{g}))$ \\
$k_{\mathrm{T}}$ & Thomas rate constant $(\mathrm{L} /(\mathrm{g} \mathrm{min}))$ \\
$k_{\mathrm{YN}}$ & Yoon-Nelson rate constant $\left(\mathrm{min}^{-1}\right)$ \\
$m$ & mass of sorbent in the column $(\mathrm{g})$ \\
$N_{0}$ & sorptive capacity of the bed $(\mathrm{mg} / \mathrm{L})$ \\
$Q$ & flow rate $(\mathrm{mL} / \mathrm{min})$ \\
$q_{0}$ & solid concentration of the solute $(\mathrm{mg} / \mathrm{g})$ \\
$q_{\mathrm{max}}$ & maximum loading according to the Langmuir equa- \\
$t$ & tion (mg/g) \\
$t_{0.5}$ & time (min) \\
$t_{\mathrm{b}}$ & time to $50 \%$ sorbate breakthrough (min) \\
$U$ & breakthrough time (min) \\
$V_{\mathrm{b}}$ & volume of solution treated at the breakthrough \\
$V_{\mathrm{ef}}$ & point $\left(\mathrm{dm}{ }^{3}\right)$ \\
$Z$ & throughput volume (L) \\
$\varepsilon$ & bed length (cm) \\
& bed porosity \\
\hline
\end{tabular}

pre-treatment to prevent fouling and microbial growth. An industrial process has been developed whereby reverse osmosis was applied to mine waters to produce a $<200 \mathrm{mg} / \mathrm{L}$ TDS drinking water [9]. Briefly, the process consisted of the following steps: (i) metals precipitation with lime, (ii) manganese removal, (iii) ultra filtration of suspended and colloidal solids, (iv) reverse osmosis/nanofiltration treatment for desalination. Around $65 \%$ of the feed water was recovered in each stage as permeate, whereas the retentate (35\% of the feed water), which had high concentration of sulfate was mixed with lime and then sent to a clarifier. The overflow of the latter fed an ultrafiltration unit prior to reverse osmosis. Such an approach enabled water recoveries as high as $99 \%$ [9]. Ion exchange resins are also applied to the treatment of AMD. Several processes have been proposed but the Sulfi-IX (formerly GYP-CYX) process, devised to sorb calcium and sulfate, is the best documented. The drainage was contacted with a strong resin in a cation-exchange circuit, which removed $\mathrm{Ca}^{2+}$ along with $\mathrm{Mg}^{2+}$, followed by a anion-exchange circuit where mainly $\mathrm{SO}_{4}{ }^{2-}$ was taken up from the drainage. The loaded resins were eluted with sulfuric acid (cationic circuit) or lime (anion circuit) and thus gypsum precipitation occurred, which required stirred tank instead of fixedbed elution. Both technologies (membrane and ion exchange) can produce pure water with very low sulfate and metal contents. The main drawbacks of such technologies are (i) fouling by gypsum; (ii) the need of downstream treatment of the concentrated waste streams (usually with high sodium and sulfate contents) and (iii) costs. Both also require some pre-treatment of the raw drainage usually by gypsum precipitation. A market for the treated water seems to be required for a cost-effective implementation of both techniques, such as in the Emalahleni Water Reclamation Plant in South Africa [9].

The removal of sulfate from mine drainages by precipitation may be carried out as: (i) gypsum precipitation with lime or limestone; (ii) barium sulfate precipitation; (iii) ettringite formation [4]. Barium sulfate precipitation can be applied to acid effluents and ensures very low residual sulfate concentrations. However, barium compounds are usually expensive whereas any residual $\mathrm{Ba}^{2+}$ ions in solution is of greater concern than the sulfate ion itself. Ettringite precipitation can also reduce sulfate concentrations to within regulatory limits and it does not utilize any toxic element (barium), but requires alkaline $\mathrm{pH}$ for effective sulfate removal [10]. Examples of industrial sulfate precipitation technologies comprise the SAVMIN and CESR (cost effective sulfate removal) processes, the integrated lime/limestone process and the BaS process [4]. The main advantage of all precipitation processes is the familiarity of the mine industry with this unit operation whereas the main drawback is the huge volume of sludge produced.

Sulfate solubility in mine waters is usually controlled by gypsum precipitation because this compound is a byproduct of lime addition to acid waters. Sulfate concentrations in equilibrium with gypsum are around $500 \mathrm{mg} / \mathrm{L}$ at infinite dilution and $25^{\circ} \mathrm{C}$, increasing to $3.0 \mathrm{~g} / \mathrm{L}$ at $I=1 \mathrm{molal}\left(25^{\circ} \mathrm{C}\right)$, thereby these values are higher than that required by environmental regulations. Accordingly, gypsum precipitation is mostly used as a first step during the treatment of mine waters with high sulfate loadings producing final anion concentrations in the $1200-2000 \mathrm{mg} / \mathrm{L}$ range [11]. Gypsum precipitation is also influenced by crystallization parameters since important differences on nucleation- and growth-rates have been reported depending on the mine water studied. It seems that crystal growth is not only controlled by mass transfer since the growth kinetics was observed to be second order with respect to supersaturation. Again, impurities in solution seem to play a pivotal role on the precipitation kinetics and secondary nucleation must be applied to overcome inhibitory effects [12].

Limestone is an alternative to lime as a neutralizer for AMD [13], but its efficiency is reduced if the mine water is only mildly acidic. The armoring effect, which is the precipitation of iron and aluminum oxyhydroxides or calcium sulfate on the limestone surface, also contributes to its lower reactivity as neutralizer. Conversely, because sulfate can also bind with calcium ions on the limestone surface, sorption can be an alternative for lowering the anion concentration, particularly in neutral mine waters, for which calcium dissolution during treatment with limestone is minimal, i.e. no gypsum precipitation is expected [14]. Therefore, in the present work, this approach is studied focusing particularly on those mine waters with moderate anion concentrations, i.e. below gypsum solubility but above the discharge limit set by environmental agencies. Accordingly, this work was performed to assess the principal parameters related to such an approach.

\section{Materials and methods}

\subsection{Calcite limestone and mine waters}

A calcite limestone sample assaying $53.7 \%$ calcium and $0.28 \%$ magnesium was kindly provided by Brazilian producers. The sample was dry-sieved using Tyler sieves. Two particle size ranges were selected for the experiments. One, with a particle size between $0.42 \mathrm{~mm}$ and $0.59 \mathrm{~mm}\left(0.77 \mathrm{~m}^{2} / \mathrm{g}\right.$ specific surface area $)$, was used in fixed-bed experiments. The other, with a particle size $<0.045 \mu \mathrm{m}$ $\left(2.05 \mathrm{~m}^{2} / \mathrm{g}\right.$ specific surface area) was selected for batch testing in a stirred reactor. The experiments were performed with neutral mine water ( $\mathrm{pH}$ 6.5) samples, assaying $588.0-1100.0 \mathrm{mg} / \mathrm{L}$ sulfate (Table 1).

\subsection{Batch experiments}

Sulfate removal kinetics experiments were performed by mixing $1.5 \mathrm{~L}$ of mine water at $\mathrm{pH} 6.5$ (initial value) containing $588.0 \mathrm{mg} / \mathrm{L} \mathrm{SO}_{4}{ }^{2-}$ with $25.0 \mathrm{~g} / \mathrm{L}$ limestone in an orbital shaker at $300 \mathrm{~min}^{-1}$ and $23 \pm 1^{\circ} \mathrm{C}$. Both particle size fractions were utilized in these experiments. Samples were withdrawn after $5 \mathrm{~min}$ in the first half hour and at 1, 2, 3, 4, 5, 6, 8 and $9 \mathrm{~h}$. At the end of the experiment, both the pulp $\mathrm{pH}$ and Eh were measured, the slurry was filtered and the sulfate concentration in the aqueous phase was determined. 
Table 1

Sulfate removal in batch experiments. Experimental conditions: $25.0 \mathrm{~g} / \mathrm{L}$ limestone $\mathrm{pH}$ initial $6.5,300 \mathrm{~min}^{-1}, 23 \pm 1^{\circ} \mathrm{C}$. Particle size: $-0.59 \mathrm{~min}+0.42 \mathrm{~mm}$.

\begin{tabular}{|c|c|c|c|}
\hline Sample & Element & $\begin{array}{l}\text { Sulfate mine water } \\
(\mathrm{mg} / \mathrm{L})\end{array}$ & $\begin{array}{l}\text { Sulfate mine water } \\
\text { after treatment }(\mathrm{mg} / \mathrm{L})\end{array}$ \\
\hline \multirow{8}{*}{$\begin{array}{l}\text { Mine water I } \\
\left(588.0 \mathrm{mg} \mathrm{SO}_{4}{ }^{2-} / \mathrm{L}\right)\end{array}$} & $\mathrm{Ca}$ & 132.9 & 141.2 \\
\hline & $\mathrm{Mn}$ & 45.0 & 1.53 \\
\hline & $\mathrm{Cu}$ & 0.65 & 0.01 \\
\hline & $\mathrm{Mg}$ & 48.0 & 36.0 \\
\hline & $\mathrm{Fe}$ & 2.4 & $<0.73$ \\
\hline & $\mathrm{Zn}$ & 0.15 & $<0.006$ \\
\hline & $\mathrm{SO}_{4}{ }^{2-}$ & 588.0 & 87.4 \\
\hline & $\mathrm{pH}$ & 6.5 & 8.1 \\
\hline \multirow{7}{*}{$\begin{array}{l}\text { Mine water II } \\
\left(800.0 \mathrm{mg} \mathrm{SO}_{4}{ }^{2-} / \mathrm{L}\right)\end{array}$} & $\mathrm{Ca}$ & 125.1 & 132.5 \\
\hline & $\mathrm{Mn}$ & 31.0 & 21.5 \\
\hline & $\mathrm{Cu}$ & 0.27 & 0.03 \\
\hline & $\mathrm{Mg}$ & 54 & 45.0 \\
\hline & $\mathrm{Fe}$ & 2.2 & $<0.73$ \\
\hline & $\mathrm{SO}_{4}{ }^{2-}$ & 800.0 & 222.4 \\
\hline & $\mathrm{pH}$ & 6.5 & 8.2 \\
\hline \multirow{7}{*}{$\begin{array}{l}\text { Mine water III } \\
\left(1100.0 \mathrm{mg} \mathrm{SO}_{4}{ }^{2-} / \mathrm{L}\right)\end{array}$} & $\mathrm{Ca}$ & 149.6 & 154.9 \\
\hline & Mn & 27 & 11 \\
\hline & $\mathrm{Cu}$ & 0.45 & 0.02 \\
\hline & $\mathrm{Mg}$ & 49 & 28 \\
\hline & $\mathrm{Fe}$ & 2.5 & $<0.73$ \\
\hline & $\mathrm{SO}_{4}{ }^{2-}$ & 1100.0 & 596.7 \\
\hline & $\mathrm{pH}$ & 7.9 & 8.1 \\
\hline
\end{tabular}

A pseudo-adsorption isotherm was produced from batch data using synthetic sulfate solutions so that the maximum limestone loading could be assessed. The procedure consisted of shaking (at $300 \mathrm{~min}^{-1}$ ) limestone particles $(0.42-0.59 \mathrm{~mm}$ ) added to $250 \mathrm{~mL}$ Erlenmeyer flasks containing $120 \mathrm{~mL}$ of sulfate solutions. The anion concentration varied from 50.0 to $3000.0 \mathrm{mg} / \mathrm{L}$ ( $\mathrm{pH}$ 9.6-9.8). The pulp contained $25.0 \mathrm{~g} / \mathrm{L}$ solids, and the experiments were run for $9 \mathrm{~h}$. Afterward, the sorption process was modeled according to the Freundlich and Langmuir equations.

\subsection{Continuous experiments}

Continuous experiments were carried out in a stirred reactor with a $1.67 \mathrm{~L}$ capacity at $23 \pm 1^{\circ} \mathrm{C}$. The reactor was fed separately with (i) $588.0 \mathrm{mg} / \mathrm{L} \mathrm{SO}_{4}{ }^{2-}$ mine water with a $\mathrm{pH}$ of 6.5 and (ii) a pulp made of limestone $(25.0 \mathrm{~g} / \mathrm{L})$ with a particle size $<0.045 \mathrm{~mm}$ and distilled water. The stirring rate was set at $1200 \mathrm{~min}^{-1}$, and pumping was provided by two peristaltic pumps (Milan 628), one feeding the mine water at $4.0 \mathrm{~mL} / \mathrm{min}$ and the other feeding the limestone pulp (at the same flow rate) to the reactor. The residence time was set at $210 \mathrm{~min}$, and the experiments ran for at least 9 residence time periods to ensure steady-state conditions. After every $210 \mathrm{~min}$, an aliquot was withdrawn from the reactor and filtered, and both the $\mathrm{pH}$ and sulfate content were measured. Prior to and during the experiments, the mine water was stored in plastic containers at room temperature.

\subsection{Fixed-bed experiments}

In the fixed-bed experiments, limestone particles $(91.92 \mathrm{~g}$, $86.94 \mathrm{~g}, 81.10 \mathrm{~g}$ and $52.85 \mathrm{~g}$ ) with an average diameter of $0.505 \mathrm{~mm}$ were transferred to a glass column ( $20 \mathrm{~mm}$ diameter) to produce different bed lengths $(Z): 250,200,150$ and $100 \mathrm{~mm}$. After loading, distilled water was passed through the column ( $60 \mathrm{~min})$ to remove any fine particles that may have been loaded in the column. The column was fed upward by a peristaltic pump so that any preferential pathway for the solution would be avoided, and the flow rate $(Q)$ was varied between 1.0 and $10.0 \mathrm{~mL} / \mathrm{min}$. Samples were collected regularly from the column effluent. The sulfate concentration in these samples was analyzed by ICP-OES (Varian 725). Sulfate loading on limestone was determined by mass balance.

\subsection{Infrared analysis and scanning electron microscopy}

Fourier transform-infrared (FT-IR) measurements were carried out by the $\mathrm{KBr}$ method using a Nicolet 6700 FT-IR spectrometer from the ThermoElectron Corporation that was equipped with a DLaTGS (deuterated lanthanum triglycine sulfate) detector and sealed CsI optics. The samples were mixed with $\mathrm{KBr}$ and mounted under the spectrometer apparatus. FT-IR spectra were recorded in the transmittance mode in the $400-4000 \mathrm{~cm}^{-1}$ region, with a minimum of 32 scans at a $4 \mathrm{~cm}^{-1}$ resolution. Automatic atmospheric suppression was applied during collection of the spectra.

Scanning electron microscopy (SEM) was used to examine the morphology of limestone particles before and after sulfate sorption. The samples were observed in a low vacuum scanning electron microscope, Inspect S50 (FEI) equipped with the software Esprit 1.9 - QUANTAX 200. The samples were mounted in an epoxy resin, before observation at $15 \mathrm{kV}$ voltage. An energy dispersive X-ray spectroscopy system (EDS) was utilized for elemental mapping.

\subsection{Chemical analysis}

Total sulfur and metal concentrations in the aqueous phase were determined by ICP-OES (Varian 725). Ion chromatography (Metrohm) indicated that total sulfur matched sulfate concentration $(2.5 \%$ error), thus sulfur concentrations (determined by ICP-OES) were stoichiometrically converted to sulfate. In addition, the anion content on the solid phase was calculated by mass balance.

\section{Kinetics modeling}

Sulfate sorption on limestone in the fixed-bed experiments was modeled by applying the following models: (i) Bohart-Adams, (ii) Thomas, (iii) Yoon and Nelson and (iv) dose-response. These models have been reviewed [15-17], and their corresponding equations are listed in Table 2. The Bohart-Adams equation assumes that the sorption rate is controlled by surface reaction, which is proportional to both the sorbent residual capacity and the sorbate concentration. This equation is applied in the development of the Bed Depth Service Time (BDST) model discussed below [18]. The Thomas model assumes that the sorption isotherm can be described 
Table 2

Models equations applied for prediction of breakthrough curve.

\begin{tabular}{lll}
\hline Model & Equation & Reference \\
\hline Bohart-Adams & $\frac{c}{C_{0}}=\frac{1}{1+\exp \left(k N_{0} Z / U-k C_{0} t\right)}$ & {$[16]$} \\
Thomas & $\frac{C}{C_{0}}=\frac{1}{1+\exp \left(\frac{k q_{0} m}{Q}-\frac{k C_{0} V}{Q}\right)}$ & {$[20]$} \\
Yoon and Nelson & $\frac{C}{C_{0}}=\frac{\exp \left(k y n t-k y n t t_{0.5}\right)}{1+\exp \left(k y n t-k y n t_{0.5}\right)}$ & {$[18]$} \\
Dose-response & $\frac{C}{C_{0}}=1-\frac{1}{1+\left(V C_{0} / m q_{0}\right)^{a}}$ & {$[20]$} \\
\hline
\end{tabular}

by the Langmuir equation and the plug flow behavior in the bed. The model also assumes that the sorption kinetics are described by the second-order reversible reaction. The main assumption of the Yoon and Nelson equation is that the rate of decrease in the sorption probability of each molecule is proportional to the probability of sorbate sorption and that of sorbate breakthrough [19]. The modified dose-response model is an empirical equation proposed by Yan et al. [17] to model fixed-bed biosorption, which was later applied to zinc [20] and chromium sorption [19].

From the Bohart-Adams equation (Table 2), the Bed Depth Service Time (BDST) model is developed when that equation is linearized to produce:

$t=\frac{N_{0} \cdot Z}{C_{0} \cdot U}-\frac{1}{k C_{0}} \ln \left(\frac{C_{0}}{C}-1\right)$

At $50 \%$ breakthrough, $C_{0} / C=2$, thus:

$t_{0.5}=\frac{N_{0} \cdot Z}{C_{0} \cdot U}$

Eq. (2) shows that the sorptive capacity of the bed $\left(N_{0}\right)$ is directly proportional to its height $(Z)$ at $50 \%$ breakthrough. Thus, $N_{0}$ can be calculated from the slope (the right-hand side of Eq. (2)) in a plot of $t_{0.5}$ versus $Z$.

\section{Results}

In this work, two approaches were applied to study sulfate sorption on limestone: (i) stirred-tank experiments utilizing fine powdered $(<0.045 \mathrm{~mm})$ limestone and (ii) sulfate removal in fixedbed columns with a coarser limestone particle size $(0.42-0.59 \mathrm{~mm})$.

\subsection{Batch removal in stirred tanks}

Preliminary experiments were carried out to compare limestone performance during sulfate sorption from either mine waters or synthetic solutions, and no significant difference was observed in the obtained results (data not shown). Therefore, only experiments performed with mine waters are reported herein.

Initially, batch experiments using sulfate-containing mine waters were carried out to define the mass of powdered limestone (particle size $<0.045 \mathrm{~mm}$ ) required for the anion removal, and $25.0 \mathrm{~g} / \mathrm{L}$ was selected for further experiments. This value enabled the sulfate concentration to be reduced from $588.0 \mathrm{mg} / \mathrm{L}$ to $162.6 \mathrm{mg} / \mathrm{L}$ within $210 \mathrm{~min}$ (Fig. 1a), while the $\mathrm{pH}$ increased from 6.5 to 8.2 , which is consistent with the $\mathrm{pH}$ values predicted for pure water in equilibrium calcium carbonate in open systems $\left(\mathrm{pCO}_{2}=10^{-3.5} \mathrm{~atm}\right)$ [21]. The sulfate concentration leveled out at $91 \mathrm{mg} / \mathrm{L}$ within $360 \mathrm{~min}$ at the same $\mathrm{pH}$ value, which represents a loading of $20 \mathrm{mg} \mathrm{SO}_{4}{ }^{2-} / \mathrm{g}$-limestone. The overall removal kinetics could be described by the pseudo-second order model, which produced a rate constant value of $2.7 \times 10^{-3} \mathrm{~g} / \mathrm{mg} \min \left(r^{2}=0.96\right)$. When coarser particles $(0.42-0.59 \mathrm{~mm}$ ) were tested (which were also utilized in the fixed-bed experiments), Fig. $1 \mathrm{~b}$, the removal kinetics were slower $\left(k=3.3 \times 10^{-4} \mathrm{~g} / \mathrm{mg} \mathrm{min}, r^{2}=0.98\right)$, but the final sulfate
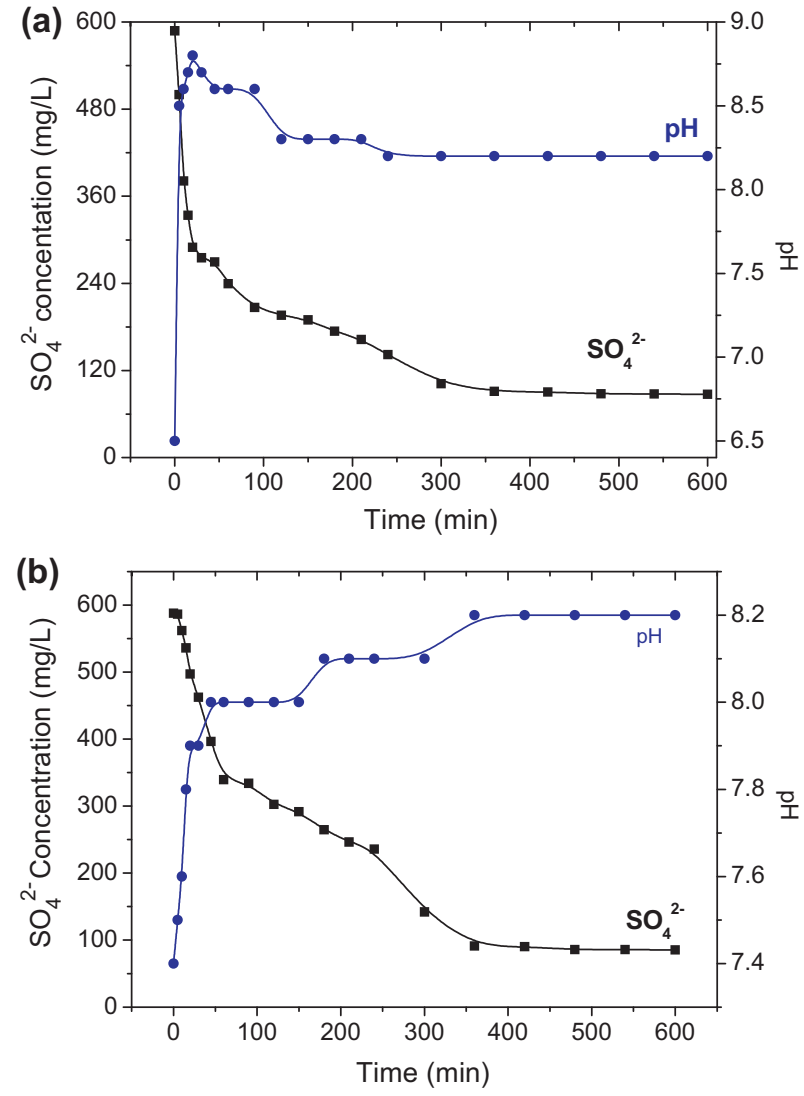

Fig. 1. Influence of time on sulfate removal and $\mathrm{pH}$. $C_{0}=588.0 \mathrm{mg} / \mathrm{L}$ sulfate, $25.0 \mathrm{~g} / \mathrm{L}$ limestone; $23 \pm 1^{\circ} \mathrm{C}$. Particle size $<0.045 \mathrm{~mm}$ (a) and $0.42-0.59 \mathrm{~mm}$ (b).

uptake on limestone was similar. Such a second order dependence suggests that the rate-limiting step may be chemical adsorption [22].

The finer limestone fraction $(<0.045 \mathrm{~mm}$ ) was applied for sulfate removal in continuous experiments. Fig. 2 shows the influence of time on sulfate removal from the $588.0 \mathrm{mg} / \mathrm{L}$ mine water. It can be observed that, with time, the $\mathrm{pH}$ increased to 8.3 (at a steady state), in agreement with the batch studies. For a $210-\mathrm{min}$ residence time, the sulfate concentration reached $87 \mathrm{mg} / \mathrm{L}$ after 10 residence time periods, which corresponds to a limestone loading of $8.3 \mathrm{mg} \mathrm{SO}_{4}{ }^{2-} / \mathrm{g}$-limestone, whereas uptakes of $10 \mathrm{mg} / \mathrm{mL}$-resin and $4.5 \mathrm{mg} / \mathrm{g}$ (at pH 4.0 ) were observed during sulfate loading on ion

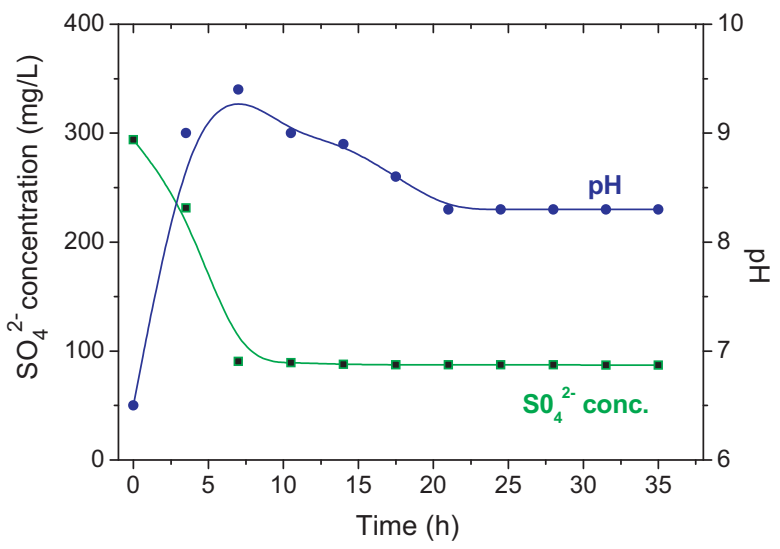

Fig. 2. Influence of time on sulfate removal and $\mathrm{pH}$ in continuous testing $C_{0}=588.0 \mathrm{mg} / \mathrm{L} ; 25.0 \mathrm{~g} / \mathrm{L}$ limestone $(<0.045 \mathrm{~mm}) ; 23 \pm 1{ }^{\circ} \mathrm{C}$. 


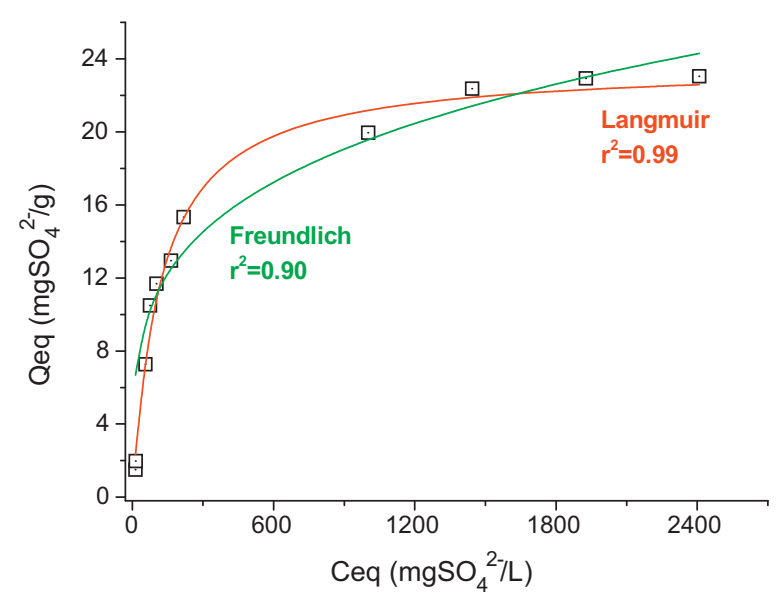

Fig. 3. Sulfate sorption isotherm at $23 \pm 1{ }^{\circ} \mathrm{C}$ and $\mathrm{pH}$ initial 6.5. Experimental conditions: $25 \mathrm{~g} / \mathrm{L}$ limestone, particle size $0.42-0.59 \mathrm{~mm}$.

exchange resin and coconut coir pitch, respectively [23,24]. Therefore, limestone shows sulfate uptakes between ion exchange resins and biological materials. Given limestone's low price, it could be a cost-effective alternative for sulfate removal from mine waters.

An alternative to stirred reactors is fixed-bed columns, which require a coarser limestone particle size fraction. Therefore, a $0.42-0.5 \mathrm{~mm}$ particle size range was utilized in the fixed-bed experiments.

\subsection{Fixed-bed sorption}

Prior to the fixed-bed experiments, a pseudo-sorption isotherm was produced so that the maximum sulfate sorption capacity could be determined (Fig. 3). Sulfate sorption on limestone was described by the Freundlich $\left(r^{2}=0.99\right)$ isotherm, and a maximum sulfate loading of $23.7 \mathrm{mg} \mathrm{SO}_{4}{ }^{2-} / \mathrm{g}$-limestone was determined. During sulfate removal from industrial wastewater by the anion exchange resin Lewatit K6362, the data were better fitted to the Freundlich than to the Langmuir isotherm [24]. Similarly, Bazer-Bachi et al. [25] investigated sulfate sorption on soil samples and observed that the Langmuir model produced a maximum loading value of $90.2 \mathrm{mg} / \mathrm{kg}$. Likewise, rice straw, a lignocellulosic agricultural residue, was chemically converted into a strong basic anion exchanger and applied for sulfate removal, showing $74.4 \mathrm{mg} / \mathrm{g}$ as the maximum adsorption capacity (Langmuir isotherm), in contrast to that of raw straw $(11.7 \mathrm{mg} / \mathrm{g})$ [3].

Fixed-bed testing was applied to sulfate removal from three different mine water sample assays: $588.0 \mathrm{mg} / \mathrm{L}, 800.0 \mathrm{mg} / \mathrm{L}$ and $1100.0 \mathrm{mg} \mathrm{SO}_{4}{ }^{2-} / \mathrm{L}$. The effects of bed height $(Z)$, flow rate $(Q)$ and initial sulfate concentration $\left(C_{0}\right)$ on sulfate sorption on limestone were assessed. Table 3 depicts key experimental parameters of the breakthrough curves presented in Fig. 4 . The breakthrough point was defined as 0.1 of $C_{0}$, while the saturation point was taken as 0.9 of $C_{0}$.

Fig. 4(a)-(d) shows the effect of different bed lengths (varying from $10 \mathrm{~cm}$ to $25 \mathrm{~cm}$ ) on the breakthrough curves for the mine water containing $588.0 \mathrm{mg} / \mathrm{L}$ sulfate. The time required for the effluent to reach the breakthrough concentration, $t_{\mathrm{b}}$, increased with increasing bed depth (Table 3 ). In addition, for the two higher bed depths, $20 \mathrm{~cm}$ (Fig. 4c) and $25 \mathrm{~cm}$ (Fig. 4d), the steepness of the curves changed and were more gradual than those achieved for the two smaller bed lengths. These effects are more pronounced for the highest flow rate $(10 \mathrm{~cm} / \mathrm{min})$ and might be ascribed to increased flow resistance at longer bed depths [16].

As expected, both breakthrough time (service time) and $t_{e}$ (saturation time) decreased at larger flow rates because of a decrease in the empty bed contact time (EBCT), Eq. (3), since at higher flow rates, the sorption front reaches the top of the column earlier [15]. Nevertheless, the breakthrough and saturation volumes increased with flow rate, along with the number of bed volumes treated at breakthrough, $N_{\mathrm{b}}$ (Table 3 ), at the same bed depth.

$\mathrm{EBCT}=\frac{A_{\mathrm{c}} Z}{Q}$

The breakthrough and saturation times were also reduced when the initial sulfate concentration was increased from $588.0 \mathrm{mg} / \mathrm{L}$ to $1100.0 \mathrm{mg} / \mathrm{L}$ (at a $25-\mathrm{cm}$ bed depth). For instance, at 800.0 and $1100.0 \mathrm{mg} / \mathrm{L}$, the breakthrough time was reduced to 98.0 and $77.3 \mathrm{~min}$, respectively. This result can be ascribed to the faster exhaustion of sorption sites, i.e., because the total number of sites available for sorption was limited, an increase in the initial concentration resulted in a faster reduction on the number of free sites [16].

Table 3

Experimental values for fixed-bed sulfate sorption by limestone for different bed depths and flow rates.

\begin{tabular}{|c|c|c|c|c|c|c|c|c|c|c|c|c|c|}
\hline$Z(\mathrm{~cm})$ & $Q(\mathrm{~mL} / \mathrm{min})$ & $C_{0}(\mathrm{mg} / \mathrm{L})$ & $\begin{array}{l}\text { Limestone } \\
\text { mass }(\mathrm{g})\end{array}$ & $U(\mathrm{~cm} / \mathrm{min})$ & $N_{\mathrm{b}}$ & $t_{b}(\min )$ & $V_{b}(\mathrm{~mL})$ & $t_{e}(\min )$ & $V_{e}(\mathrm{~mL})$ & $t_{0.5}(\min )$ & $\mathrm{EBCT}(\mathrm{min})$ & $\operatorname{AUR}(\mathrm{g} / \mathrm{mL})$ & $\operatorname{MTZ}(\mathrm{cm})$ \\
\hline 10 & 1 & 588.0 & 52.8 & 0.32 & 3.6 & 111.7 & 111.7 & 275.0 & 275.0 & 193.4 & 31.4 & 0.47 & 5.9 \\
\hline 15 & 1 & 588.0 & 81.1 & 0.32 & 2.9 & 135.3 & 135.3 & 316.1 & 316.1 & 225.7 & 47.1 & 0.60 & 8.6 \\
\hline 20 & 1 & 588.0 & 86.9 & 0.32 & 2.7 & 167.7 & 167.7 & 383.1 & 383.1 & 275.4 & 62.8 & 0.52 & 11.3 \\
\hline 25 & 1 & 588.0 & 91.9 & 0.32 & 2.6 & 206.0 & 206.0 & 406.7 & 406.7 & 306.3 & 78.5 & 0.45 & 12.3 \\
\hline 10 & 2 & 588.0 & 52.8 & 0.64 & 5.4 & 85.2 & 170.4 & 292.8 & 585.6 & 180.9 & 15.7 & 0.31 & 7.1 \\
\hline 15 & 2 & 588.0 & 81.1 & 0.64 & 4.5 & 106.6 & 213.2 & 297.4 & 594.8 & 202.0 & 23.5 & 0.38 & 9.6 \\
\hline 20 & 2 & 588.0 & 86.9 & 0.64 & 4.0 & 126.6 & 253.2 & 342.2 & 684.4 & 234.4 & 31.4 & 0.34 & 12.6 \\
\hline 25 & 2 & 588.0 & 91.9 & 0.64 & 4.3 & 170.8 & 341.6 & 421.4 & 842.8 & 284.5 & 39.3 & 0.27 & 14.9 \\
\hline 10 & 3 & 588.0 & 52.8 & 0.95 & 6.2 & 65.4 & 196.2 & 237.6 & 712.8 & 151.6 & 10.5 & 0.27 & 7.3 \\
\hline 15 & 3 & 588.0 & 81.1 & 0.95 & 4.4 & 70.0 & 210.0 & 245.7 & 737.1 & 157.8 & 15.7 & 0.39 & 10.7 \\
\hline 20 & 3 & 588.0 & 86.9 & 0.95 & 5.0 & 104.0 & 312.0 & 304.7 & 914.1 & 204.3 & 20.9 & 0.28 & 13.2 \\
\hline 25 & 3 & 588.0 & 91.9 & 0.95 & 5.7 & 150.2 & 450.6 & 363.6 & 1090.8 & 256.9 & 26.2 & 0.20 & 14.7 \\
\hline 10 & 10 & 588.0 & 52.8 & 3.2 & 12.0 & 37.7 & 376.9 & 118.0 & 1180.2 & 77.9 & 3.1 & 0.14 & 6.8 \\
\hline 15 & 10 & 588.0 & 81.1 & 3.2 & 12.5 & 59.1 & 591.0 & 199.1 & 1991.4 & 129.1 & 4.7 & 0.14 & 10.6 \\
\hline 20 & 10 & 588.0 & 86.9 & 3.2 & 13.0 & 81.9 & 819.0 & 262.4 & 2624.5 & 172.2 & 6.3 & 0.11 & 13.8 \\
\hline 25 & 10 & 588.0 & 91.9 & 3.2 & 17.4 & 137.1 & 1370.8 & 338.7 & 3386.6 & 237.9 & 7.9 & 0.07 & 14.9 \\
\hline 25 & 10 & 800.0 & 91.9 & 3.2 & 12.5 & 98.0 & 980.4 & 298.3 & 2983.3 & 198.2 & 7.9 & 0.09 & 16.8 \\
\hline 25 & 10 & 1100.0 & 91.9 & 3.2 & 9.8 & 77.3 & 772.7 & 248.9 & 2489.3 & 163.1 & 7.9 & 0.12 & 17.2 \\
\hline
\end{tabular}



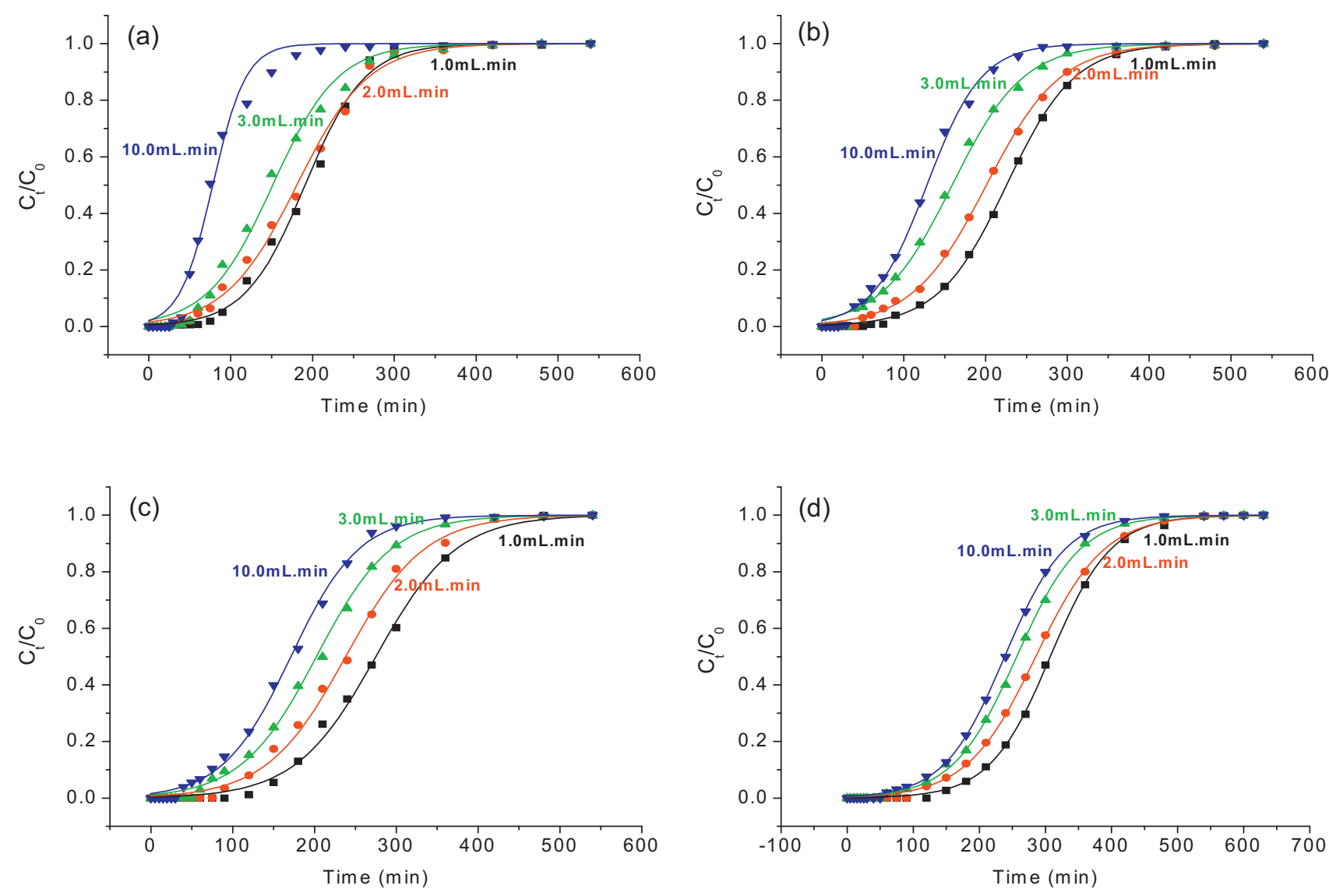

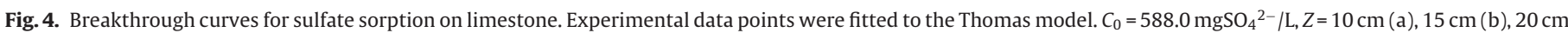
(c), $25 \mathrm{~cm}(\mathrm{~d}) ; 23 \pm 1^{\circ} \mathrm{C}$.

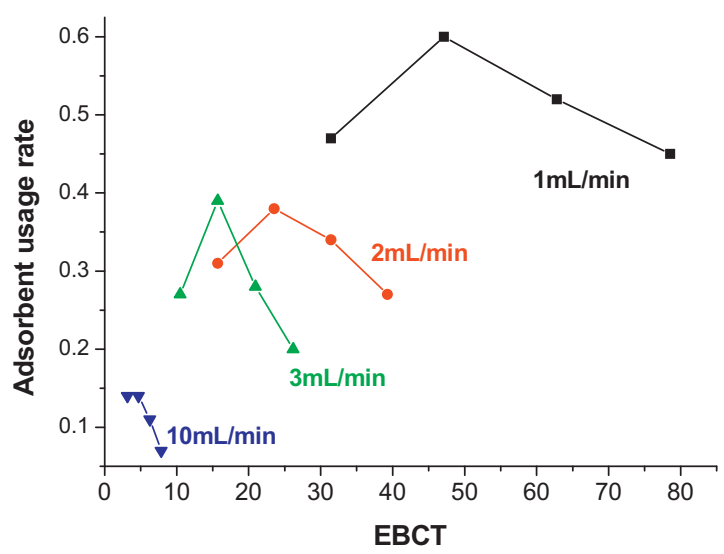

Fig. 5. EBRT plot for the sorption of sulfate ions on limestone. $C_{0}=588 \mathrm{mg} / \mathrm{L}$; $23 \pm 1{ }^{\circ} \mathrm{C}$.

The Empty Bed Contact Time (EBCT), Eq. (3) and the adsorbent usage rate (AUR), defined as the weight of sorbent saturated per volume of treated solution (Eq. (4)) are also given in Table 3.

$\mathrm{AUR}=\frac{m_{\mathrm{c}}}{V_{\mathrm{b}}}$

The EBCT affects the volume to breakthrough and the shape of the breakthrough curve, as previously discussed. From Fig. 5, it can be seen that for the 15 - to 25 - $\mathrm{cm}$ bed lengths, the sorbent usage rate decreases with increasing EBCT, as was also observed by Srivastava et al. [16] and Singh et al. [15]. The mass transfer zone (MTZ), as defined by Aguayo-Villarreal et al. [26], represents between 50\% and $70 \%$ of the bed depth.

\subsection{Breakthrough modeling}

Sulfate sorption on calcite limestone was modeled by applying the equations depicted in Table 2, namely: (i) Bohart-Adams; (ii) Thomas; (iii) Yoon and Nelson; and (iv) dose-response [16,19].

Fig. 6 shows the BDST plot for sulfate sorption on limestone for bed heights varying from $10 \mathrm{~cm}$ to $25 \mathrm{~cm}$ at both $10 \%$ and $50 \%$ breakthrough and for four different flow rates $(1-10 \mathrm{~mL} / \mathrm{min})$. The bed sorption capacity $\left(N_{0}\right)$ was calculated from the slopes of both the $10 \%$ and $50 \%$ breakthrough plots, and the results are shown in Table 4. It can be observed that the sulfate loading on limestone beds increases with flow rate until reaching $19.7 \mathrm{~g} / \mathrm{L}$-bed (at $10 \mathrm{~cm} / \mathrm{min}$ ), which is lower than the value ( $51.3 \mathrm{~g} / \mathrm{L}$-bed) achieved for sulfate sorption on the Amberlite IRA458 resin, at pH 2.0 [27].

The sorption rate constant can be determined from the $10 \%$ breakthrough plot, and Eq. (1) predicts that the intercept should be a negative value. As shown in Table 4, the intercepts at both $1 \mathrm{~mL} / \mathrm{min}$ and $2 \mathrm{~mL} / \mathrm{min}$ are positive, which is a violation of the BDST theory. Therefore, the rate constant was not determined for such flow rate values. Nevertheless, the flow rate value of $3 \mathrm{~mL} / \mathrm{min}$ seems to provide faster limestone sorption on limestone $\left(k=1.056 \times 10^{-3} \mathrm{~L} / \mathrm{g} \mathrm{min}\right)$ compared with the experiments carried out with a $10 \mathrm{~mL} / \mathrm{min}$ flow rate $\left(k=1.12 \times 10^{-4} \mathrm{~L} / \mathrm{g} \mathrm{min}\right)$, although such figures does not seem to represent the physical process. Furthermore, as predicted by Eq. (4), the plot of $t_{0.5}$ versus $Z$ should be a straight line passing through the origin. However, Fig. 6 shows that the linear plot does not demonstrate such behavior, which indicates that the sulfate sorption on limestone is a complex phenomenon 

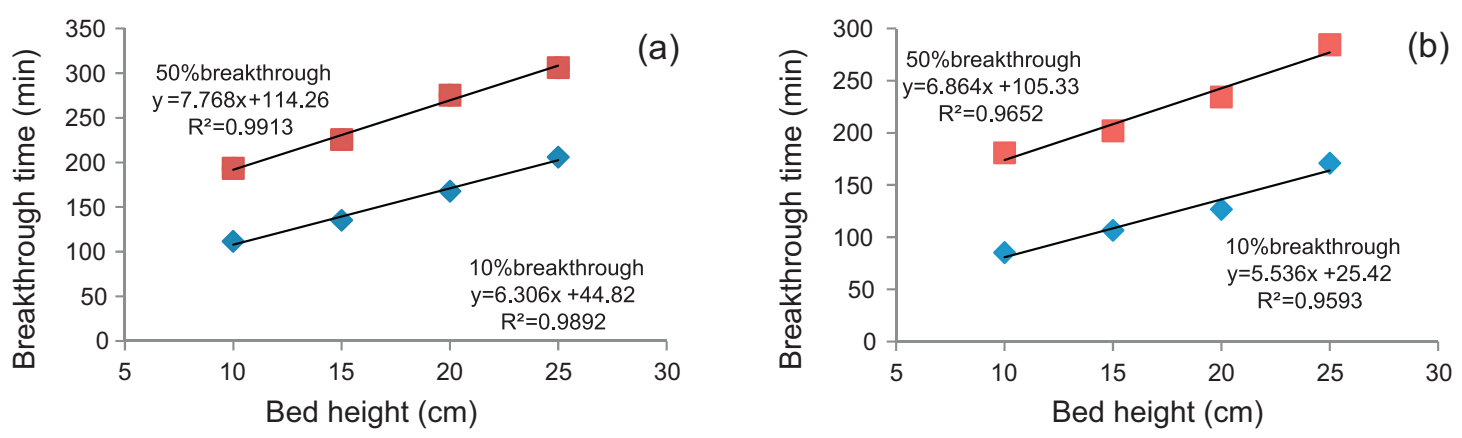

(b)
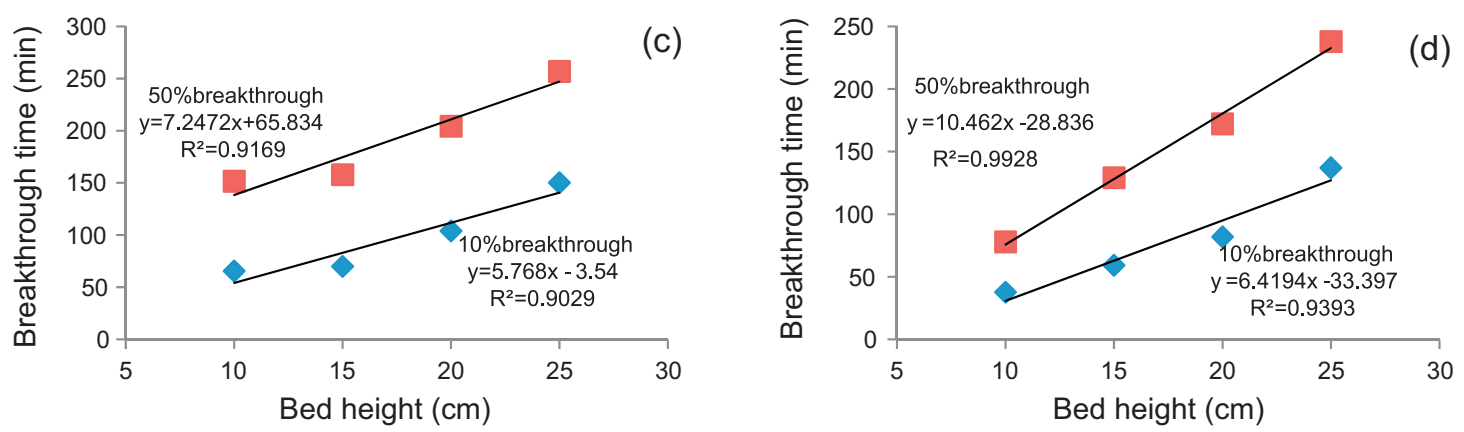

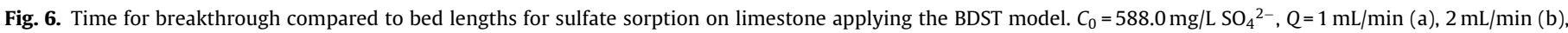
$3 \mathrm{~mL} / \mathrm{min}(\mathrm{c})$, and $10 \mathrm{~mL} / \mathrm{min}(\mathrm{d})$.

Table 4

Bed capacity, rate constant and slope values for sulfate loading on limestone at different flow rates, according to the BDST model.

\begin{tabular}{|c|c|c|c|}
\hline \multirow[t]{2}{*}{ Flow rate $(\mathrm{mL} / \mathrm{min})$} & \multicolumn{2}{|c|}{ Bed capacity (g/L-bed) } & \multirow[t]{2}{*}{ Rate constant $\left(\times 10^{-4} \mathrm{~L} / \mathrm{mg} \mathrm{min}\right)$} \\
\hline & $10 \%$ breakthrough & $50 \%$ breakthrough & \\
\hline 1 & 1.187 & 1.462 & - \\
\hline 2 & 2.083 & 2.583 & - \\
\hline 3 & 3.222 & 4.048 & 10.56 \\
\hline 10 & 12.079 & 19.685 & 1.12 \\
\hline \multirow[t]{2}{*}{ Flow rate $(\mathrm{mL} / \mathrm{min})$} & \multicolumn{2}{|l|}{ Slope } & \\
\hline & $10 \%$ breakthrough & $50 \%$ breakthrough & \\
\hline 1 & 6.31 & 7.77 & \\
\hline 2 & 5.54 & 6.84 & \\
\hline 3 & 5.77 & 7.24 & \\
\hline 10 & 6.42 & 10.46 & \\
\hline
\end{tabular}

that likely involves more than one rate-limiting step, as will be discussed further in this work [16]. The BDST theory also predicts (Eq. (2)) that the service time at different flow rates should increase linearly with the inverse of the axial velocity $(U)$. However, this correlation is not followed in the present work because the slope at $50 \%$ breakthrough actually increased with the flow rate (from 2 to $10 \mathrm{~mL} / \mathrm{min}$ ), as shown in Table 4.

In addition to the BDST model, 3 different equations were applied to model the breakthrough curves produced during sulfate sorption on calcite limestone: (i) Thomas, (ii) Yoon and Nelson and (iii) dose-response [16,19]. Tables 5 and 6 present model parameters for three mine water samples (588.0-1100.0 mg/L) and all equations produced good correlation coefficients between the models and the experimental data $\left(r^{2}=0.99\right)$.

Applying the Thomas model to the experimental data, the values of the kinetic constant $\left(k_{\mathrm{T}}\right)$ and the limestone sorption capacity $\left(q_{0}\right)$ were determined, as shown in Table 5 while, the breakthrough curves are shown in Fig. 4. It can be observed in Table 5 that the values of the limestone sorption capacities increased with increasing flow rates $(Q)$. When the bed dept was increased from $15 \mathrm{~cm}$ to $25 \mathrm{~cm}$, the sulfate loading values were below $2.0 \mathrm{mg} \mathrm{SO}_{4}{ }^{2-} / \mathrm{g}$-limestone at $1 \mathrm{~mL} / \mathrm{min}$, but they increased to at least to $9.4 \mathrm{mg} \mathrm{SO}_{4}{ }^{2-} / \mathrm{g}$-limestone when the flow rate was set at $10 \mathrm{~mL} / \mathrm{min}$. In the experiment performed with the $1100.0 \mathrm{mg} / \mathrm{L}$ mine water, sulfate loading was $19.3 \mathrm{mg} / \mathrm{g}$-limestone, which is close to the maximum loading $(23.7 \mathrm{mg} / \mathrm{g})$ indicated by the Langmuir equation (Fig. 3). Therefore, an increase in flow rate causes a decrease in the film resistance and a positive effect on mass transfer unlike the BDST theory. At $10 \mathrm{~mL} / \mathrm{min}$, the effect of the bed depth on the rate constant becomes stronger compared with the shorter bed lengths. It can be observed that up to a $3 \mathrm{~mL} / \mathrm{min}$ flow rate, the rate constant, $k$, is approximately $20-25 \%$ higher for the $10-\mathrm{cm}$ bed depth compared with the $25-\mathrm{cm}$ bed depth. Nevertheless, at $10 \mathrm{~cm} / \mathrm{min}$, the rate constant achieved for the lower bed depth is 2.5 times the value determined for the $25-\mathrm{cm}$ bed length (Table 5), a result of increased flow resistance at larger bed depths.

Applying the Yoon and Nelson equation, Table 6 indicates that the determined $t_{0.5}$ values are similar to the experimental values. The rate constant $\left(k_{y N}\right)$ along with the Thomas rate constant $\left(k_{\mathrm{T}}\right)$ are affected by flow rate only for the 10 and $15 \mathrm{~cm}$ bed depths, which 
Table 5

Parameters predicted using the Thomas model for sulfate sorption on limestone at $23 \pm 1^{\circ} \mathrm{C}$.

\begin{tabular}{|c|c|c|c|c|c|}
\hline Bed depth $(\mathrm{cm})$ & $Q(\mathrm{~mL} / \mathrm{min})$ & $C_{0}(\mathrm{mg} / \mathrm{L})$ & $k_{\mathrm{T}}(\mathrm{L} /(\mathrm{g} \min ))$ & $q_{0}(\mathrm{mg} / \mathrm{g}$-limestone) & $R^{2}$ \\
\hline \multirow{4}{*}{10} & 1 & 588 & 0.047 & 2.15 & 0.99 \\
\hline & 2 & 588 & 0.039 & 4.03 & 0.99 \\
\hline & 3 & 588 & 0.043 & 5.06 & 0.99 \\
\hline & 10 & 588 & 0.084 & 8.69 & 0.99 \\
\hline \multirow{4}{*}{15} & 1 & 588 & 0.041 & 1.64 & 0.99 \\
\hline & 2 & 588 & 0.038 & 2.93 & 0.99 \\
\hline & 3 & 588 & 0.039 & 3.43 & 0.99 \\
\hline & 10 & 588 & 0.051 & 9.36 & 0.99 \\
\hline \multirow{4}{*}{20} & 1 & 588 & 0.035 & 1.86 & 0.99 \\
\hline & 2 & 588 & 0.035 & 3.17 & 0.99 \\
\hline & 3 & 588 & 0.037 & 4.14 & 0.99 \\
\hline & 10 & 588 & 0.041 & 11.65 & 0.99 \\
\hline \multirow{6}{*}{25} & 1 & 588 & 0.037 & 1.96 & 0.99 \\
\hline & 2 & 588 & 0.033 & 3.65 & 0.99 \\
\hline & 3 & 588 & 0.035 & 4.93 & 0.99 \\
\hline & 10 & 588 & 0.037 & 15.22 & 0.99 \\
\hline & 10 & 800 & 0.028 & 17.65 & 0.99 \\
\hline & 10 & 1100 & 0.023 & 19.34 & 0.99 \\
\hline
\end{tabular}

Table 6

Parameters predicted using both Yoon and Nelson as well as dose-response Thomas model for sulfate sorption on limestone at $23 \pm 1{ }^{\circ} \mathrm{C}$.

\begin{tabular}{|c|c|c|c|c|c|c|c|c|}
\hline \multicolumn{2}{|l|}{ Parameters } & \multicolumn{4}{|c|}{ Yoon and Nelson model } & \multicolumn{3}{|l|}{ Dose-response model } \\
\hline Bed depth $(\mathrm{cm})$ & $Q(\mathrm{~mL} / \mathrm{min})$ & $C_{0}(\mathrm{mg} / \mathrm{L})$ & $k_{\mathrm{YN}}\left(\min ^{-1}\right)$ & $t_{0.5}(\min )$ & $R^{2}$ & $q_{0}(\mathrm{mg} / \mathrm{g}$-limestone) & $a$ & $R^{2}$ \\
\hline \multirow{4}{*}{10} & 1 & 588 & 0.030 & 193.5 & 0.99 & 2.05 & 4.8 & 0.99 \\
\hline & 2 & 588 & 0.020 & 183.3 & 0.99 & 3.9 & 3.9 & 0.99 \\
\hline & 3 & 588 & 0.025 & 151.5 & 0.99 & 4.73 & 3.3 & 0.99 \\
\hline & 10 & 588 & 0.050 & 77.9 & 0.99 & 8.48 & 3.6 & 0.99 \\
\hline \multirow{4}{*}{15} & 1 & 588 & 0.024 & 225.66 & 0.99 & 1.6 & 5.4 & 0.99 \\
\hline & 2 & 588 & 0.022 & 201.68 & 0.99 & 2.83 & 4.2 & 0.99 \\
\hline & 3 & 588 & 0.024 & 156.53 & 0.99 & 3.24 & 3.4 & 0.99 \\
\hline & 10 & 588 & 0.03 & 128.36 & 0.99 & 8.53 & 3.45 & 0.99 \\
\hline \multirow{4}{*}{20} & 1 & 588 & 0.020 & 274.29 & 0.99 & 1.81 & 5.5 & 0.99 \\
\hline & 2 & 588 & 0.021 & 237.93 & 0.99 & 3.13 & 4.56 & 0.99 \\
\hline & 3 & 588 & 0.022 & 202.3 & 0.99 & 3.98 & 4.2 & 0.99 \\
\hline & 10 & 588 & 0.024 & 171.09 & 0.99 & 11.27 & 3.8 & 0.99 \\
\hline \multirow{6}{*}{25} & 1 & 588 & 0.022 & 308.11 & 0.99 & 1.61 & 5.3 & 0.99 \\
\hline & 2 & 588 & 0.019 & 284.26 & 0.99 & 3.57 & 5.3 & 0.99 \\
\hline & 3 & 588 & 0.020 & 256.36 & 0.99 & 4.88 & 5.2 & 0.99 \\
\hline & 10 & 588 & 0.022 & 238.29 & 0.99 & 14.88 & 4.9 & 0.99 \\
\hline & 10 & 800 & 0.022 & 195.17 & 0.99 & 16.42 & 4.1 & 0.99 \\
\hline & 10 & 1100 & 0.025 & 165.4 & 0.99 & 18.99 & 4.0 & 0.99 \\
\hline
\end{tabular}

highlights the increased flow resistance for longer bed depths. By applying the dose-response model to the experimental data (Table 6), it can be seen that the sulfate loadings on the limestone particles, $q_{0}$, were similar to those determined by the Thomas model and that they increased with flow rate at the same bed depth. Conversely, limestone loading was not particularly affected by bed depth (at the same flow rate), excluding the experiment carried out with the $10 \mathrm{~mL} / \mathrm{min}$ flow rate, in which limestone loading increased with bed depth. Such a result is likely due to a larger contact time between the sulfate-containing mine water and the limestone particles at larger column depths.

\section{Discussion}

The Bohart-Adams model assumes a rectangular isotherm [28], which is an approximation of the actual isotherm depicted in Fig. 3. In addition, the straight line describing service time versus bed depth does not pass through the origin (Fig. 6), which indicates that the sorption process is complex, as already stated. Furthermore, comparing the intercepts at $10 \%$ breakthrough, it can be observed that this parameter is reduced (from +44.8 to -33.4 ) for increasing flow rates. This result suggests that the mass transfer resistance in the solid phase is not predominant; otherwise, the observed

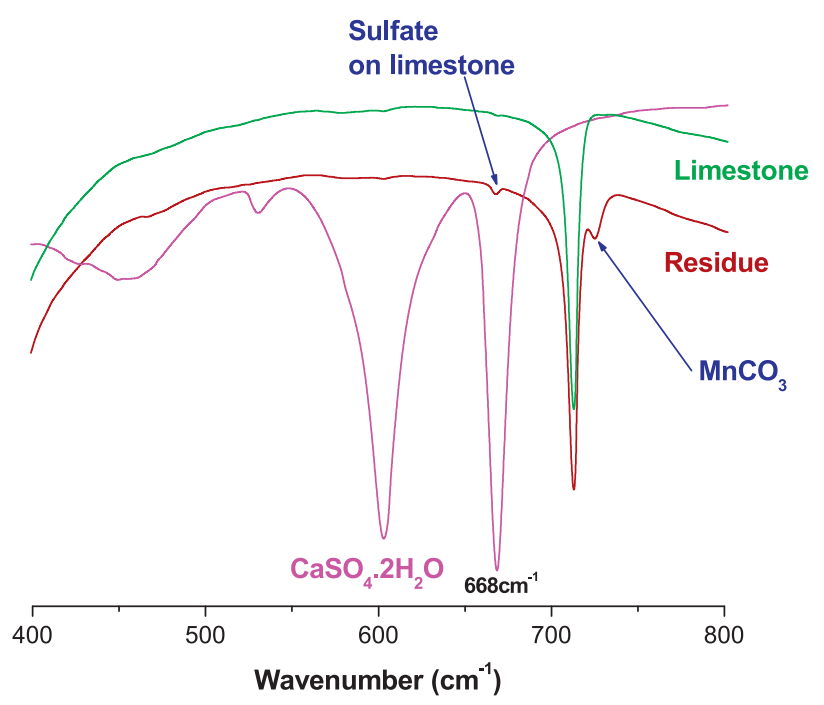

Fig. 7. Infrared spectra for limestone, calcium sulfate di-hydrate and sulfate-laden limestone. 
(a)

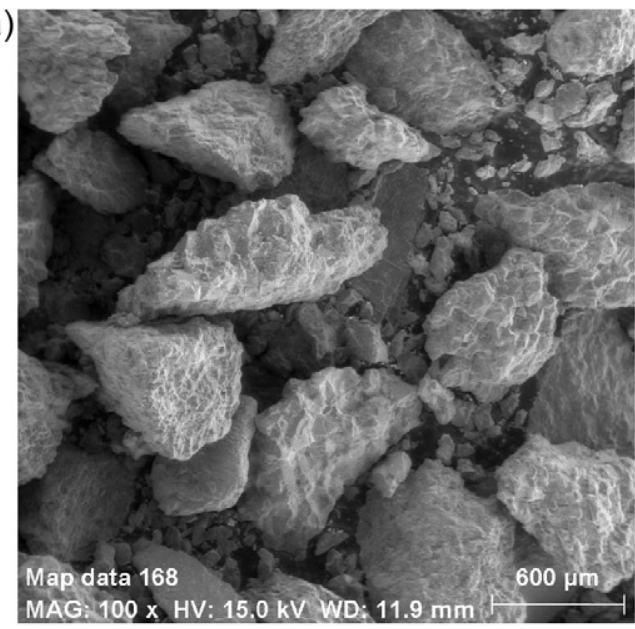

(c)

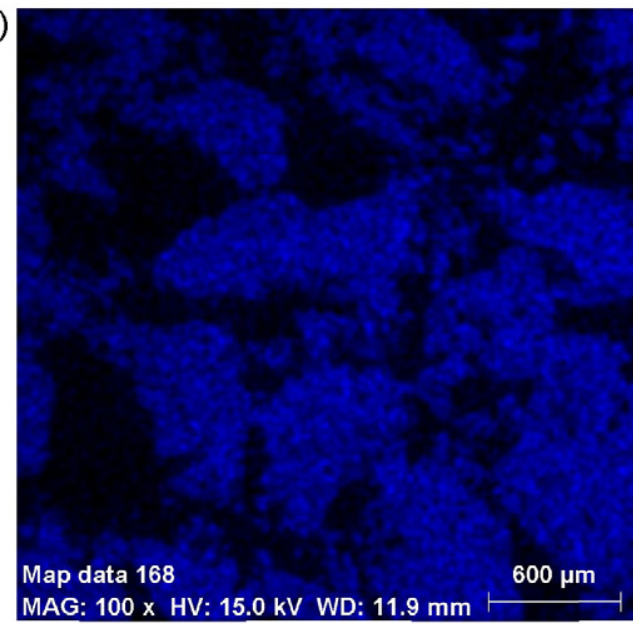

(e)

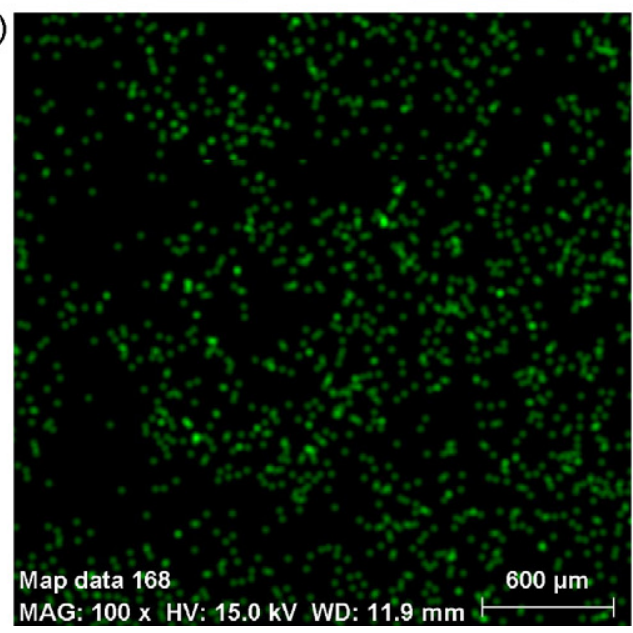

(b)

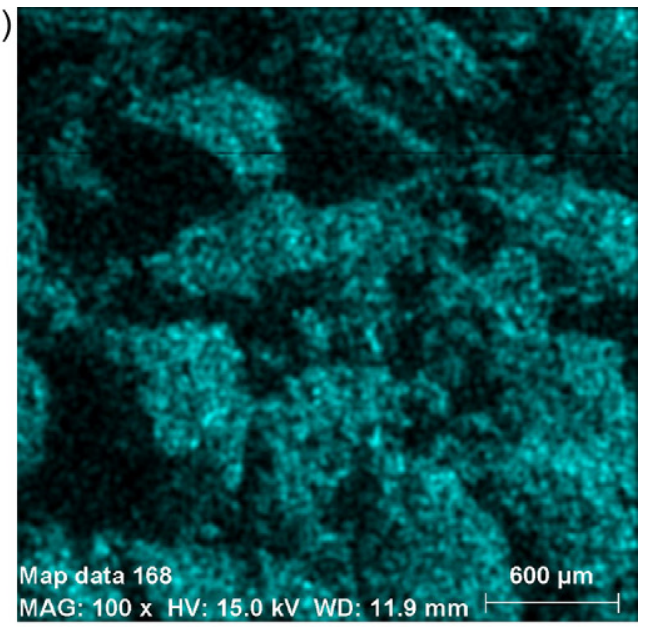

(d)

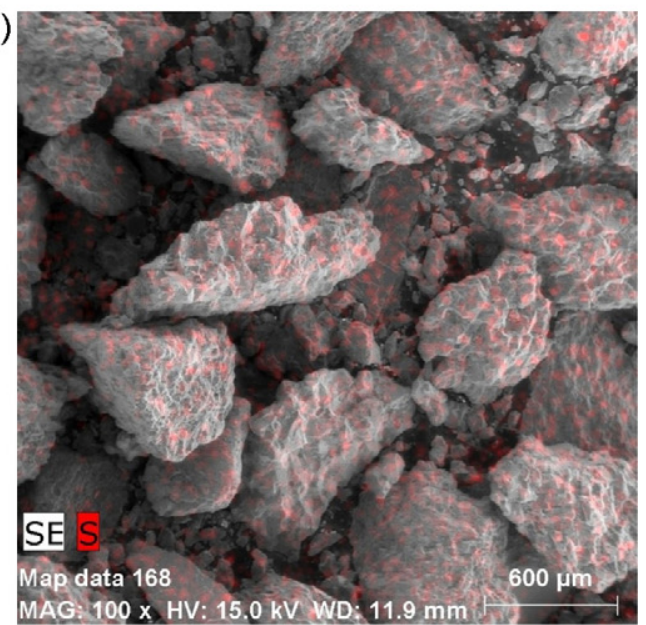

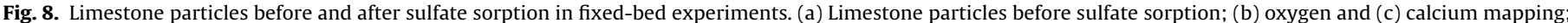

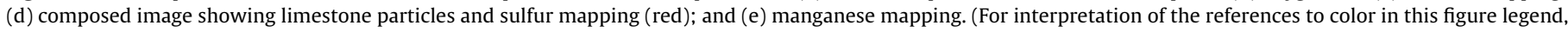
the reader is referred to the web version of the article.)

intercept values would not be significantly affected by changes in the flow rate, as discussed by Cooney [28]. This scenario may likely be a result of the low surface area of the limestone particles, which do not present significant porosity. Chemical reactions, which are not thought to control the sorption process kinetics, may play an important role in the sulfate sorption on limestone and this is reinforced by the second-order kinetics observed in the batch kinetics experiments.
The sorption mechanism was analyzed by Infrared spectroscopy. Fig. 7 shows an infrared spectrum for the limestone particles after sulfate uptake in stirred tank experiments (Fig. 2). Also shown are the spectra of both pure limestone and di-hydrate calcium sulfate. The sulfate ions show fundamental vibrations due to symmetric (at $981 \mathrm{~cm}^{-1}$ ) and asymmetric $\left(1104 \mathrm{~cm}^{-1}\right.$ ) stretching vibrations. Symmetric and asymmetric bending vibrations are observed at 451 and $613 \mathrm{~cm}^{-1}$, respectively. In the range 
of $400-800 \mathrm{~cm}^{-1}, \mathrm{CaSO}_{4} \cdot 2 \mathrm{H}_{2} \mathrm{O}$ shows a doublet at $668 \mathrm{~cm}^{-1}$ and $603 \mathrm{~cm}^{-1}$ due to $v_{4}\left(\mathrm{SO}_{4}{ }^{2}\right)$ bending vibrations [29]. Pure limestone shows a strong $C=O$ IR shift at $712 \mathrm{~cm}^{-1}$ [30]. The spectrum of the sulfate-loaded limestone shows a peak at $668 \mathrm{~cm}^{-1}$, which suggests the presence of sulfate ions on the limestone surface, but the absence of the $603 \mathrm{~cm}^{-1}$ band indicates that a different calcium sulfate compound has actually formed. Nevertheless, this observation requires further investigation. Sulfate likely binds to $>\mathrm{CaOH}_{2}{ }^{+}$sites (>denotes the edge of the bulk calcite surface), which is the predominant calcium species on limestone surface in neutral (5.5-8.0) $\mathrm{pH}$ values [31]. Another important outcome observed in figure 10 is the peak at $725 \mathrm{~cm}^{-1}$, which can be ascribed to the presence of manganese carbonate on the limestone surface. As shown in Table 1, this mine water contains 30-45 mg/L manganese, which has been shown to sorb on limestone as manganese carbonate [32].

SEM-EDS were applied to further characterize the limestone particles before and after sulfate removal. Fig. 8a depicts limestone particles before mixing with the $588.0 \mathrm{mg} \mathrm{SO}_{4}{ }^{2-} / \mathrm{L}$ mine water in fixed bed experiments. Fig. $8 \mathrm{~b}$ and c shows, respectively, oxygen and calcium mapping confirming the nature of limestone particles. A composed image (Fig. 8d) showing limestone particles and sulfur mapping (red) suggests sorption as the only removal mechanism. Bulk calcium sulfate precipitation, which might have occurred from limestone dissolution (which is observed when acid waters is treated with the latter) did not seem to be important herein because the studied mine water is neutral ( $\mathrm{pH}$ 6.5). This is supported by the results in Table 1 that show low calcium dissolution during sulfate removal.

An analysis of some of the chemical species present in the three studied mine water samples (Table 1 ) suggests that these species were removed during treatment with limestone. Manganese is a major toxic element in this mine water, and it cannot be completely removed by limestone, although soluble carbonate sources would improve its precipitation [33]. Nevertheless, the manganese concentration was reduced in the best case to $1.5 \mathrm{mg} / \mathrm{L}$, which implies that the mine water would require further treatment for its removal before discharge. Manganese mapping is depicted in Fig. 8e, which shows the element is dispersed in the whole limestone particles. Minor toxic metals, such as copper and zinc, were also removed.

Sorption (either precipitation or adsorption) on the limestone surface is the mechanism accounting for sulfate removal [34]. The findings of the present work suggest that surface reaction is part of the sorption mechanism. The second-order kinetics observed in the batch studies; the good fitting to the Langmuir isotherm along with the infra-red results support sulfate chemisorption on limestone. From the hypothesis of each tested model for fixed-bed sorption, the Thomas model appears to be the most suitable for describing the breakthrough curves.

Limestone can be utilized as an alternative to lime in the treatment of AMD. As the solid is dissolved, calcium ions are released and gypsum is precipitated. As an example, Maree et al. [8] treated acidic coal discard leachate containing $8.4 \mathrm{~g} / \mathrm{LSO}_{4}{ }^{2-}$ by a combination of limestone neutralization and biological sulfate reduction. In the neutralization step, $\mathrm{pH}$ was increased from 1.8 to 6.6 whereas the sulfate concentration was reduced from $8.4 \mathrm{~g} / \mathrm{L}$ to $2.0 \mathrm{~g} / \mathrm{L}$ after mixing with limestone powder. Limestone was also successfully applied in the treatment of a Fe(II)-containing acid mine water, whereby the $\mathrm{pH}$ was raised to 6.6 [35]. Neutralization was carried out in a fixed-bed reactor and a high-solids-content sludge was produced, which supported secondary gypsum nucleation [12]. However, the Limestone dissolution rate is strongly reduced when the drainage $\mathrm{pH}$ is increased (almost three orders of magnitude when the $\mathrm{pH}$ increases from 2.0 to 5.0), i.e. it is ineffective for neutral drainages.
Irrespective of which calcium source is applied (either lime or limestone, if the mine water has sufficient acidity for dissolving the calcium carbonate), gypsum precipitation will define the final sulfate concentration in the process. In such conditions, gypsum solubility constraints will result in sulfate concentrations never below $1200 \mathrm{mg} / \mathrm{L}[12,36]$, which does not comply with most environmental regulations. Nevertheless, for those mine waters with high sulfate concentrations, lime precipitation still seems to be the best technical and economical alternative because of its high efficiency in reducing sulfate concentrations regardless of the $\mathrm{pH}$ of the process. However, if sulfate concentrations in the mine water are below this range (as in the three mine water samples currently studied) so that the system is undersaturated with respect to gypsum, the route herein proposed (sulfate sorption) is a cost-effective alternative that can remove sulfate to concentrations that comply with environmental regulations. Such technology would be particularly suitable for those countries where water is widely available and where mine water treatment costs must remain as low as possible because there is no possibility to commercialize the treated water.

\section{Conclusions}

This work showed that limestone can be a cost-effective alternative to treating mine waters with sulfate concentrations below the values defined by gypsum solubility $(1200-2000 \mathrm{mg} / \mathrm{L})$ and where only more expensive processes are available. Sulfate sorption on limestone can be described by the Langmuir isotherm, which showed a maximum uptake of $23.7 \mathrm{mg} / \mathrm{g}$-limestone. Fine powdered limestone $(<0.045 \mathrm{~mm})$ can be applied to treat moderate sulfate concentrations $(588.0 \mathrm{mg} / \mathrm{L})$ in stirred reactors, whereby sulfate concentrations can be lowered to below $100 \mathrm{mg} / \mathrm{L}$. Alternatively, fixed-bed experiments can be utilized to produce sulfate uptakes as high as $20 \mathrm{~g} / \mathrm{L}$-bed, while the sorption process can be described by simple models, such as the Thomas, Yoon and Nelson and dose-response equations. The BDST model can be applied for design purposes, whereas the process seems to be mostly film diffusion-controlled because the flow rate has important effects on the fixed-bed sorption.

\section{Acknowledgments}

The financial support from the funding agencies FINEP, FAPEMIG, CNPq and CAPES is gratefully appreciated. The assistance of Vallourec \& Sumitomo Tubos do Brasil Ltda with the SEM-EDS analysis is also acknowledged.

\section{References}

[1] D.R. Mulinari, M.L.C.P. da Silva, Adsorption of sulphate ions by modification of sugarcane bagasse cellulose, Carbohydrate Polymers 74 (3) (2008) 617-620, http://dx.doi.org/10.1016/j.carbpol.2008.04.014.

[2] P. Roonasi, A. Holmgren, An ATR-FTIR study of sulphate sorption on magnetite; rate of adsorption, surface speciation, and effect of calcium ions, Journal of Colloid and Interface Science. 333 (1) (2009) 27-32, http://dx.doi.org/10.1016/j.jcis.2008.12.080.

[3] J. Cao, G. Zhang, Z. Mao, Z. Fang, C. Yang, Precipitation of valuable metals from bioleaching solution by biogenic sulfides, Minerals Engineering. 22 (3) (2009) 289-295, http://dx.doi.org/10.1016/j.mineng.2008.08.006.

[4] INAP, Treatment of sulphate in mine effluentes, International network for acid prevention 2003.

[5] A. Kaksonen, P. Franzmann, J. Puhakka, Performance and ethanol oxidation kinetics of a sulfate-reducing fluidized-bed reactor treating acidic metal-containing wastewater, Biodegradation 14 (3) (2003) 207-217, http://dx.doi.org/10.1023/a:1024262607099.

[6] J. Shayegan, F. Ghavipanjeh, P. Mirjafari, The effect of influent COD and upward flow velocity on the behaviour of sulphatereducing bacteria, Process Biochemistry 40 (7) (2005) 2305-2310, http://dx.doi.org/10.1016/j.procbio.2004.09.005.

[7] S.M. Bertolino, I.C.B. Rodrigues, R. Guerra-Sá, S.F. Aquino, V.A. Leão, Implications of volatile fatty acid profile on the metabolic pathway during 
continuous sulfate reduction, Journal of Environmental Management (2012) 15-23, http://dx.doi.org/10.1016/j.jenvman.2012.02.022.

[8] J.P. Maree, G. Strobos, H. Greben, E. Netshidaulu, E. Steyn, A. Christie, P. Gunther, F.B. Waanders, Treatment of acid leachate from coal discard using calcium carbonate and biological sulphate removal, Mine Water and the Environment 23 (3) (2004) 144-151, http://dx.doi.org/10.1007/s10230-004-0055-x.

[9] V.E. Cogho, A.M. van Niekerk, Optimum coal mine water reclamation project, in: International Mine Water Conference, Pretoria, South Africa, 2009, pp. 415-430.

[10] B.C.S. Ferreira, R.M.F. Lima, V.A. Leão, Remoção de sulfato de efluentes industriais por precipitação, Engenharia Sanitária e Ambiental 16 (2) (2012) 1-8.

[11] A.J. Geldenhuys, J.P. Maree, M.P.H. de Beer, An integrated limestone/lime process for partial sulphate removal, The Journal of The South African Institute of Mining and Metallurgy 103 (6) (2003) 345-354.

[12] S. Tait, W.P. Clarke, J. Keller, D.J. Batstone, Removal of sulfate from high-strength wastewater by crystallisation, Water Research 43 (3) (2009) 762-772.

[13] Q. Sun, L.M. McDonald Jr., J.G. Skousen, Effects of armoring on limestone neutralization of AMD, in: 2000 West Virginia Surface Mine Drainage Task Force Symposium, Morgantown, WV, 2000, pp. 1-10.

[14] J.P. Maree, P. Du Plessis, C.J. Van der Walt, Treatment of acidic effluents with limestone instead of lime, Water Science and Technology. 26 (1-2) (1992) 345-355.

[15] S. Singh, V.C. Srivastava, I.D. Mall, Fixed-bed study for adsorptive removal of furfural by activated carbon, Colloids and Surfaces A: Physicochemical and Engineering Aspects. 332 (1) (2009) 50-56, http://dx.doi.org/10.1016/j.colsurfa.2008.08.025.

[16] V.C. Srivastava, B. Prasad, I.M. Mishra, I.D. Mall, M.M. Swamy, Prediction of breakthrough curves for sorptive removal of phenol by Bagasse fly ash packed bed, Industrial \& Engineering Chemistry Research 47 (5) (2008) 1603-1613, http://dx.doi.org/10.1021/ie0708475.

[17] G. Yan, Viraraghavan, T. Viraraghavan, M. Chen, A new model for heavy metal removal in a biosorption column, Adsorption Science \& Technology 19 (1) (2001) 25-43.

[18] R. Kumar, D. Bhatia, R. Singh, S. Rani, N.R. Bishnoi, Sorption of heavy metals from electroplating effluent using immobilized biomass Trichoderma viride in a continuous packed-bed column, International Biodeterioration \& Biodegradation 65 (8) (2011) 1133-1139.

[19] M. Calero, F. Hernáinz, G. Blázquez, G. Tenorio, M.A. Martín-Lara, Study of Cr(III) biosorption in a fixed-bed column, Journal of Hazardous Materials 171 (1-3) (2009) 886.

[20] R. Senthilkumar, K. Vijayaraghavan, M. Thilakavathi, P.V.R. Iyer, M. Velan, Seaweeds for the remediation of wastewaters contaminated with zinc(II) ions, Journal of Hazardous Materials 136 (3) (2006) 791-799, http://dx.doi.org/10.1016/j.jhazmat.2006.01.014.

[21] R.M. Garrels, C.L. Christ, Solutions, Minerals, and Equilibria, Jones \& Bartlett Publishers International, London, 1990.

[22] H. Qiu, L. Lv, B.-c. Pan, Q.-j. Zhang, W.-m. Zhang, Q.-x. Zhang, Critical review in adsorption kinetic models, Journal of Zhejiang University - Science A 10 (5) (2009) 716-724.
[23] C. Namasivayam, D. Sangeetha, Application of coconut coir pith for the removal of sulfate and other anions from water, Desalination 219 (1-3) (2008) 1-13, http://dx.doi.org/10.1016/j.desal.2007.03.008.

[24] R. Haghsheno, A. Mohebbi, H. Hashemipour, A. Sarrafi, Study of kinetic and fixed bed operation of removal of sulfate anions from an industrial wastewater by an anion exchange resin, Journal of Hazardous Materials 116 (2-3) (2009) 961-966, http://dx.doi.org/10.1016/j.jhazmat.2008.12.009.

[25] F. Bazer-Bachi, M. Descostes, E. Tevissen, P. Meier, B. Grenut, M.O. Simonnot, M. Sardin, Characterization of sulphate sorption on Callovo-Oxfordian argillites by batch, column and through-diffusion experiments, Physics and Chemistry of the Earth, Parts A/B/C 32 (8-14) (2007) 552-558, http://dx.doi.org/10.1016/j.pce.2006.01.010.

[26] I.A. Aguayo-Villarreal, A. Bonilla-Petriciolet, V. Hernández-Montoya, M.A. Montes-Morán, H.E. Reynel-Avila, Batch and column studies of $\mathrm{Zn}^{2+}$ removal from aqueous solution using chicken feathers as sorbents, Chemical Engineering Journal 167 (1) (2011) 67-76, http://dx.doi.org/10.1016/j.cej.2010.11.107.

[27] D. Guimarães, V.A. Leão, Studies of sulfate ions removal by the polyacrylic anion exchange resin Amberlite IRA458: batch and fixed-bed column studies, in: T.R. Rude, A. Freund, C. Wolkersdorfer (Eds.), IMWA Congress 2011, Aachen, Germany, 2011, pp. 337-342.

[28] D.O. Cooney, Adsorption Design for Wastewater Treatment, Lewis Publishers, Boca Raton, 1999.

[29] G. Anbalagan, S. Mukundakumari, K.S. Murugesan, S. Gunasekaran, Infrared, optical absorption, and EPR spectroscopic studies on natural gypsum, Vibrational Spectroscopy 50 (2) (2009) 226-230, http://dx.doi.org/10.1016/j.vibspec.2008.12.004.

[30] J. Santillán, Q. Williams, A high-pressure infrared and X-ray study of $\mathrm{FeCO}_{3}$ and $\mathrm{MnCO}_{3}$ : comparison with $\mathrm{CaMg}\left(\mathrm{CO}_{3}\right)_{2}$-dolomite, Physics of The Earth and Planetary Interiors 143/144 (2004) 291-304, http://dx.doi.org/10.1016/j.pepi.2003.06.007.

[31] P. Van Cappellen, L. Charlet, W. Stumm, P. Wersin, A surface complexation model of the carbonate mineral-aqueous solution interface, Geochimica et Cosmochimica Acta 57 (15) (1993) 3505-3518, http://dx.doi.org/10.1016/00167037(93)90135-j.

[32] A.M. Silva, F.L.S. Cruz, R.M.F. Lima, M.C. Teixeira, V.A. Leão, Manganese and limestone interactions during mine water treatment, Journal of Hazardous Materials 181 (1-3) (2010) 514, http://dx.doi.org/10.1016/j.jhazmat.2010.05.044.

[33] A.M. Silva, E.C. Cunha, F.D. Reis, V.A. Leão, Treatment of high-manganese mine water with limestone and sodium carbonate, Journal of Cleaner Production (2012) 11-19, http://dx.doi.org/10.1016/j.jclepro.2012.01.032.

[34] G. Rangel-Porras, J.B. García-Magno, M.P. González-Muñoz, Lead and cadmium immobilization on calcitic limestone materials, Desalination 262 (1-3) (2010) 1-10, http://dx.doi.org/10.1016/j.desal.2010.04.043.

[35] J.P. Maree, M. Beer, W.F. Strydom, A.D.M. Christie, F.B. Waanders, Neutralizing coal mine effluent with limestone to decrease metals and sulphate concentrations, Mine Water and the Environment 23 (2) (2004) 81-86.

[36] J.P. Maree, P. Du Plessis, Neutralization of acid mine water with calcium carbonate, Water Science and Technology 29 (9) (1994) 285-296. 